\title{
Co-Electrolysis of Steam and Carbon Dioxide in Solid Oxide Cells
}

\author{
Ebbesen, Sune Dalgaard; Knibbe, Ruth; Mogensen, Mogens Bjerg
}

Published in:

Journal of The Electrochemical Society

Link to article, DOI:

10.1149/2.076208jes

Publication date:

2012

Document Version

Publisher's PDF, also known as Version of record

Link back to DTU Orbit

Citation (APA):

Ebbesen, S. D., Knibbe, R., \& Mogensen, M. B. (2012). Co-Electrolysis of Steam and Carbon Dioxide in Solid Oxide Cells. Journal of The Electrochemical Society, 159(8), F482-F489. https://doi.org/10.1149/2.076208jes

\section{General rights}

Copyright and moral rights for the publications made accessible in the public portal are retained by the authors and/or other copyright owners and it is a condition of accessing publications that users recognise and abide by the legal requirements associated with these rights.

- Users may download and print one copy of any publication from the public portal for the purpose of private study or research.

- You may not further distribute the material or use it for any profit-making activity or commercial gain

- You may freely distribute the URL identifying the publication in the public portal 


\section{Co-Electrolysis of Steam and Carbon Dioxide in Solid} Oxide Cells

Sune Dalgaard Ebbesen, Ruth Knibbe and Mogens Mogensen

J. Electrochem. Soc. 2012, Volume 159, Issue 8, Pages F482-F489. doi: 10.1149/2.076208jes

Email alerting Receive free email alerts when new articles cite this article - sign up service in the box at the top right corner of the article or click here

To subscribe to Journal of The Electrochemical Society go to: http://jes.ecsdl.org/subscriptions 


\title{
Co-Electrolysis of Steam and Carbon Dioxide in Solid Oxide Cells
}

\author{
Sune Dalgaard Ebbesen, ${ }^{\mathrm{Z}}$ Ruth Knibbe, ${ }^{\mathrm{a}}$ and Mogens Mogensen*
}

Department of Energy Conversion and Storage, Technical University of Denmark, 4000 Roskilde, Denmark

Reduction of $\mathrm{H}_{2} \mathrm{O}$ and $\mathrm{CO}_{2}$ as well as oxidation of $\mathrm{H}_{2}$ and $\mathrm{CO}$ was studied in a Ni/YSZ electrode supported Solid Oxide Cell (SOC) produced at DTU Energy conversion (former Ris $\varnothing$ DTU). Even though these Ni/YSZ based SOCs were developed and optimized for fuel cell use, they can work as reversible SOCs in mixtures of $\mathrm{H}_{2} \mathrm{O}, \mathrm{H}_{2}, \mathrm{CO}_{2}$ and $\mathrm{CO}$. From polarization (i-V) and electrochemical impedance spectroscopic characterization, it is evident that, electrochemical reduction of both $\mathrm{CO}_{2}$ and $\mathrm{H}_{2} \mathrm{O}$ occurs during coelectrolysis of $\mathrm{H}_{2} \mathrm{O}$ and $\mathrm{CO}_{2}$ in these Ni/YSZ based SOC. During co-electrolysis, the equilibrium of the water gas shift reaction is reached, and $\mathrm{CO}$ is therefore produced via the water gas shift reaction also. Significant differences during oxidation/reduction in $\mathrm{H}_{2} \mathrm{O}-\mathrm{H}_{2}$ and $\mathrm{CO}_{2}-\mathrm{CO}$ mixtures were observed implying that different reaction mechanisms apply for the mixtures. (C) 2012 The Electrochemical Society. [DOI: 10.1149/2.076208jes] All rights reserved.

Manuscript submitted April 12, 2012; revised manuscript received June 4, 2012. Published July 20, 2012.

In recent years there has been an increased focus on hydrogen as an alternative energy carrier because of limited fossil fuel sources, increasing oil prices and environmental considerations. However, the conversion to a hydrogen-based infrastructure will require major investments as the already existing infrastructure is based upon liquid hydrocarbons. Production of synthetic hydrocarbon fuels from renewable energy is a solution to reduce oil consumption and carbon dioxide emissions without the need for modifications of existing infrastructure. The raw material for synthetic hydrocarbon fuels is synthesis gas $\left(\mathrm{H}_{2}+\mathrm{CO}\right)$, which traditionally is produced via coal gasification or steam reforming of natural gas. Both processes consume fossil fuels and emit green-house gases. Simultaneous electrolysis of steam and carbon dioxide (co-electrolysis, $\mathrm{H}_{2} \mathrm{O}+\mathrm{CO}_{2} \rightarrow \mathrm{H}_{2}+\mathrm{CO}+\mathrm{O}_{2}$ ) using renewable energy sources may be an alternative route for producing synthesis gas without consuming fossil fuels or emitting green-house gases. Also in line with the transformation toward renewable electricity, producing synthetic hydrocarbon fuels from electricity may be a solution to the increasing need for electricity storage.

Water (steam) electrolysis $\left(\mathrm{H}_{2} \mathrm{O} \rightarrow \mathrm{H}_{2}+1 / 2 \mathrm{O}_{2}\right)$ in Solid Oxide Cells (SOC) for hydrogen production was under development during the early 1980 'es ${ }^{1,2}$ and has again become increasingly investigated during recent years as a green energy technology. ${ }^{3,4}$ Only limited studies have reported electrolysis of $\mathrm{CO}_{2}\left(\mathrm{CO}_{2} \rightarrow \mathrm{CO}+1 / 2 \mathrm{O}_{2}\right)$ in SOCs. ${ }^{2,5-21}$ These studies were performed on SOCs based on metal cermet electrodes of palladium, platinum or nickel..$^{2,5-21}$ The first studies of $\mathrm{CO}_{2}$ electrolysis were performed in platinum and nickel based SOCs at NASA as a means for producing oxygen., ${ }^{2,9-11,13,15}$ Co-electrolysis has only been shown in a few studies, ${ }^{7,21-27}$ and there are discrepancies whether $\mathrm{CO}$ is produced via the reverse water gas shift reaction solely and that no electrolysis of $\mathrm{CO}_{2}$ occur ${ }^{25,26}$ or if $\mathrm{CO}$ is produced both via the reverse water gas shift reaction and via electrolysis of $\mathrm{CO}_{2} \cdot{ }^{7,23}$

It is the aim of the present study to investigate the reaction mechanism during co-electrolysis and to investigate the reaction mechanism of the electrochemical reduction of $\mathrm{H}_{2} \mathrm{O}$ and $\mathrm{CO}_{2}$, as well as oxidation of $\mathrm{H}_{2}$ and $\mathrm{CO}$ in mixtures of $\mathrm{H}_{2} \mathrm{O}-\mathrm{H}_{2}, \mathrm{CO}_{2}-\mathrm{CO}$ and $\mathrm{H}_{2} \mathrm{O}-\mathrm{CO}_{2}$ $-\mathrm{H}_{2}-\mathrm{CO}$ to gain insight in the reaction mechanism and to establish the effect of the Water Gas Shift (WGS)/Reverse Water Gas Shift (RWGS) reaction.

\section{Experimental}

Planar Ni/YSZ supported SOCs of $5 \times 5 \mathrm{~cm}^{2}$ with an active electrode area of $4 \times 4 \mathrm{~cm}^{2}$ were used for the experiments. The cell was produced at DTU Energy conversion (former Ris $\emptyset$ DTU), ${ }^{28,29}$ and have a 10-15 $\mu \mathrm{m}$ thick Ni/YSZ cermet electrode; a $10-15 \mu \mathrm{m}$ thick YSZ electrolyte and a 15-20 $\mu \mathrm{m}$ thick strontium-doped lanthanum man-

*Electrochemical Society Active Member.

${ }^{a}$ Present address: Superconductivity and Energy Group, Industrial Research Limited,

New Zealand.

${ }^{\mathrm{z} E-m a i l: ~ s u e b @ d t u . d k}$ ganate (LSM) composite oxygen electrode. The cells are supported by a $\sim 300 \mu \mathrm{m}$ thick porous Ni/YSZ layer. ${ }^{29,30}$ At start-up, the nickel oxide in the Ni/YSZ electrode is reduced to nickel in hydrogen at $1000^{\circ} \mathrm{C}$

For characterizing the cell, a test house as described elsewhere ${ }^{21,31}$ was used. The cell was sandwiched between the gas distributor components, which were contacted with a gold foil on the LSM/YSZ electrode and a nickel foil on the Ni/YSZ electrode to pick up the electrode current. The gas distributor component (ACC) on the LSM/YSZ electrode side was made of the same material as the electrode. The gas distributor component on the Ni/YSZ electrode was made from a nickel mesh. The cell was sealed at its edges between the two alumina blocks using glass bars on the LSM/YSZ electrode side and a platinum sealing on the Ni/YSZ electrode side. Platinum was used as sealing instead of glass to avoid silica evaporation from the glass sealing resulting in cell passivation/degradation, as previously published ${ }^{32}$ (Since the cell was reduced at $1000^{\circ} \mathrm{C}$, platinum (and not gold) was applied because of the high melting point). The gas channels for inlet and outlet gas were in the alumina block. The test house was placed in a furnace to operate the cell at the desired temperature. Analysis of the gas inlet and outlet was performed by a gas chromatograph $(6890 \mathrm{~N}$, Agilent Technologies) equipped with a thermal conductivity detector (TCD) and a Hayesep N column.

After reduction, the cell was characterized in $\mathrm{H}_{2} \mathrm{O}-\mathrm{H}_{2}$ mixtures following a standard procedure at DTU Energy conversion (former Risø DTU). This procedure includes AC and DC characterization with various gas atmosphere supplied to the Ni/YSZ electrode (4/96, $20 / 80$ or $50 / 50 \mathrm{H}_{2} \mathrm{O}-\mathrm{H}_{2}$ ), and pure oxygen or air supplied to the LSM/YSZ electrode (Technical air, Air Liquide)). Steam was produced by reacting oxygen (industrial grade, $\mathrm{O}_{2} \geq 99.5 \%$ ), Air Liquide) with hydrogen ( $\mathrm{N} 30, \mathrm{H}_{2} \geq 99.9 \%$, Air Liquide) at the inlet to the cell housing. The exothermic nature of the steam production causes a slight increase in temperature; the cell temperature is constantly monitored and the furnace temperature is regulated to keep the cell temperature constant.

To investigate the feasibility of co-electrolysis in these Ni/YSZ based SOCs, additional $\mathrm{AC}$ and $\mathrm{DC}$ characterization was performed in $\mathrm{H}_{2} \mathrm{O}-\mathrm{H}_{2}, \mathrm{CO}_{2}-\mathrm{CO}, \mathrm{CO}_{2}-\mathrm{H}_{2}$ or $\mathrm{CO}_{2}-\mathrm{H}_{2} \mathrm{O}-\mathrm{CO}$ mixtures at the $\mathrm{Ni} / \mathrm{YSZ}$ electrode. In all experiments shown in the present study, pure oxygen $(20 \mathrm{~L} / \mathrm{h})$ was flown to the LSM/YSZ electrode in order to avoid any transients in the polarization resistance.

DC characterization of the cell was performed by recording polarization curves ( $\mathrm{i}-\mathrm{V}$ curves) in both electrolysis and fuel cell mode by varying the current. The Area Specific cell Resistance (ASR) was calculated from the $\mathrm{i}-\mathrm{V}$ curves as the chord from Open Circuit Voltage $(\mathrm{OCV})$ to the cell voltage measured at a current density of $-0.16 \mathrm{~A} \cdot \mathrm{cm}^{-2}$ (electrolysis mode) or $0.16 \mathrm{~A} \cdot \mathrm{cm}^{-2}$ (fuel cell mode). The uncertainty for the ASRs calculated from the measured $\mathrm{i}-\mathrm{V}$ curves is less than one percent.

$\mathrm{AC}$ characterization at $\mathrm{OCV}$ was performed by Electrochemical Impedance Spectroscopy (EIS) using an external shunt and a Solartron 1260 frequency analyzer at frequencies from $82 \mathrm{kHz}$ to $0.08 \mathrm{~Hz}$ with 
Table I. Break down of the polarization resistances for the SOCs produced at DTU Energy conversion (former Risø DTU) when characterized in $25 \% \mathrm{H}_{2} \mathrm{O}-75 \% \mathrm{H}_{2}$ at the $\mathrm{Ni} / \mathrm{YSZ}$ electrode and air at the LSM/YSZ electrode at $700^{\circ} \mathrm{C}$ and $850^{\circ} \mathrm{C} .33$

\begin{tabular}{llcc} 
& & \multicolumn{2}{c}{ Resistance $\left(\Omega \cdot \mathrm{cm}^{2}\right)$} \\
\cline { 3 - 4 } & Circuit & $700^{\circ} \mathrm{C}$ & $850^{\circ} \mathrm{C}$ \\
\hline 1 & LSM $_{\mathrm{Hi}}$ & $0.22-0.35$ & $0.05-0.07$ \\
2 & $\mathrm{TPB}$ & $0.24-0.36$ & $0.05-0.08$ \\
3 & LSM & $0.36-0.51$ & $0.03-0.06$ \\
4 & Diffusion & $0.02-0.03$ & $0.02-0.03$ \\
5 & Conversion & $\sim 0.06$ & $\sim 0.06$
\end{tabular}

an amplitude of $3.75 \mathrm{~A} / \mathrm{cm}^{2}$ with 6 points per dacade. The impedance data were corrected using the short-circuit impedance response of the test set-up.

Data treatment.- To break down the impedance contributions from each of the two electrodes, the impedance spectra were fitted to an equivalent circuit consisting of an inductance, a serial resistance, and five RQ-equivalent circuits - as previously described for this type of Ni/YSZ based SOCs produced at DTU Energy conversion (former Ris $\varnothing$ DTU). ${ }^{33}$ When characterizing the aforementioned cells with $25 \% \mathrm{H}_{2} \mathrm{O}-75 \% \mathrm{H}_{2}$ supplied to the $\mathrm{Ni} / \mathrm{YSZ}$ electrode and air to the LSM/YSZ electrode the five circuits represent a high frequency $\mathrm{LSM} / \mathrm{YSZ}$ electrode arc $\left(\mathrm{R}_{\mathrm{LSM}-\mathrm{High}}\right)$, a contribution from the TPB reaction in the $\mathrm{Ni} / \mathrm{YSZ}$ electrode $\left(\mathrm{R}_{\mathrm{TPB}}\right)$, a low frequency LSM/YSZ electrode $\operatorname{arc}\left(\mathrm{R}_{\mathrm{LSM} \text { - Low }}\right)$, a diffusion arc $\left(\mathrm{R}_{\text {Diffusion }}\right)$ and a gas conversion arc $\left(R_{\text {Conversion }}\right)$. $R_{\text {Diffusion }}$ and $R_{\text {Conversion originate from the Ni/YSZ }}$
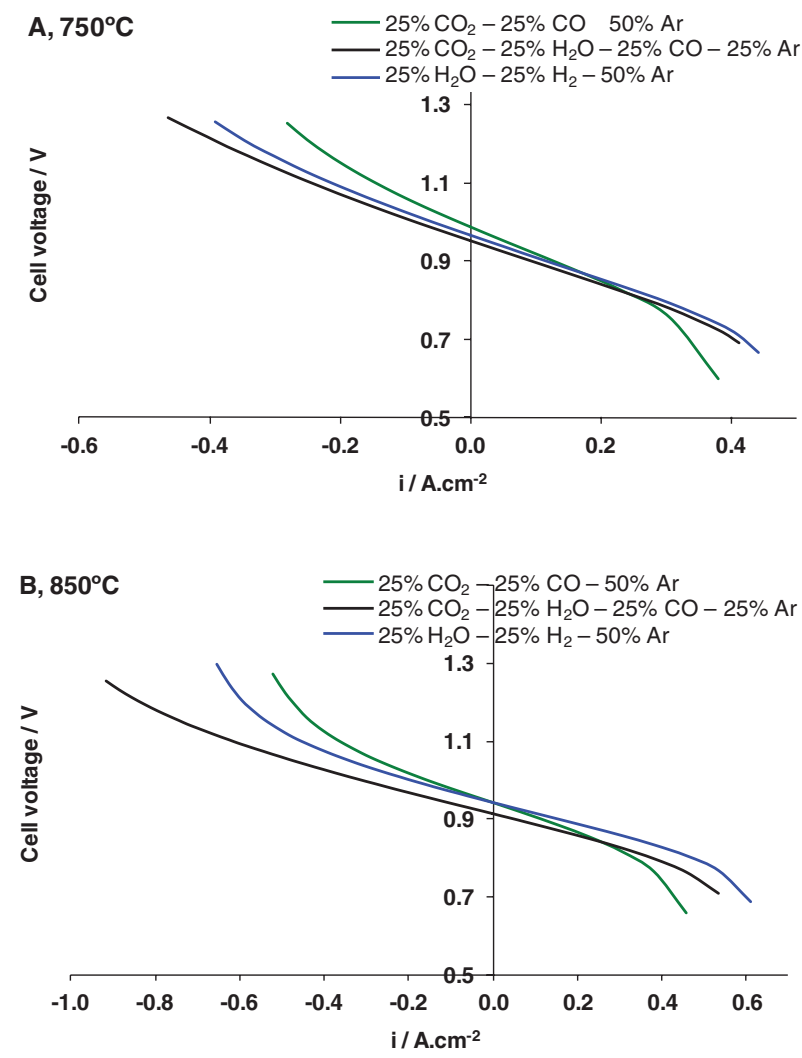

Figure 1. DC characterization at $750^{\circ} \mathrm{C}(\mathrm{A})$ and $850^{\circ} \mathrm{C}(\mathrm{B})$ in $25 \% \mathrm{CO}_{2}$ $-25 \% \mathrm{CO}-50 \% \mathrm{Ar}, 25 \% \mathrm{CO}_{2}-25 \% \mathrm{H}_{2} \mathrm{O}-25 \% \mathrm{CO}-25 \% \mathrm{Ar}$, or $25 \%$ $\mathrm{H}_{2} \mathrm{O}-25 \% \mathrm{H}_{2}-50 \%$ Ar gas mixtures. electrode. The resistances for each of the five circuits when characterizing the SOCs produced at DTU Energy conversion (former Ris $\emptyset$ DTU) with $25 \% \mathrm{H}_{2} \mathrm{O}-75 \% \mathrm{H}_{2}$ supplied to the $\mathrm{Ni} / \mathrm{YSZ}$ and air supplied to the $\mathrm{LSM} / \mathrm{YSZ}$ electrode at $700^{\circ} \mathrm{C}$ and $850^{\circ} \mathrm{C}$ are listed in Table I..$^{33}$ The resistances listed in Table I can only be used as a guideline because variation in performance between the produced cells occur, and since other resistances will certainly be observed when changing the gas compositions, i.e. steam content to the Ni/YSZ electrode and oxygen content to the LSM/YSZ electrode. ${ }^{33,34}$ The impedance spectra recorded in $25 \% \mathrm{H}_{2} \mathrm{O}-25 \% \mathrm{H}_{2}-50 \% \mathrm{Ar}$ was used as a basis for the remaining fit. This initial fit was obtained by keeping the exponent of the constant phase elements constant. ${ }^{33}$ For the remaining mixtures, first, the contribution to the Ni/YSZ electrode was fitted (since only the gas composition to the Ni/YSZ electrode was changed) followed by fitting the contribution to the LSM/YSZ electrode. For these two subsequent fitting routines the exponents of constant phase element of the respective processes were always kept constant. Finally a free fit of the inductance, and the capacitance and resistance for all the arcs was performed.

\section{Results}

Figure 1 shows two sets of three i- $\mathrm{V}$ curves measured in electrolysis and fuel cell mode at $750^{\circ} \mathrm{C}$ and $850^{\circ} \mathrm{C}$ for $\mathrm{H}_{2} \mathrm{O}-\mathrm{H}_{2}, \mathrm{CO}_{2}-\mathrm{CO}$ or $\mathrm{H}_{2} \mathrm{O}-\mathrm{CO}_{2}-\mathrm{CO}$ mixtures (the exact gas compositions are indicated in the figure). The gas compositions and calculated ASR for the six polarization characterisations are shown in Table II. The balance of the gas mixtures supplied to the Ni/YSZ electrode was made with Argon in all experiments. The experiments were performed in random order (at each temperature) and all i-V curves and impedance spectra were reproducible. Pure oxygen was supplied to the LSM/YSZ electrode. Since oxygen was supplied to the LSM/YSZ electrode in all experiments, only the gas composition to the Ni/YSZ electrode will be stated below. For simplicity, the inert argon concentration will only be stated in the figures and tables, and not in the text.

The measured ASR for $\mathrm{CO}_{2}$ electrolysis was slightly higher than for both co-electrolysis and steam electrolysis. The lowest ASR was observed for co-electrolysis at the present conditions (Figure 1, Table II). In fuel cell mode, the highest ASR was observed for CO oxidation; whereas similar ASRs were measured for oxidation of $\mathrm{H}_{2}$ and $\mathrm{CO}$ when both $\mathrm{CO}_{2}$ and $\mathrm{H}_{2} \mathrm{O}$ were present - co-electrolysis conditions (Table II). The corresponding electrochemical impedance
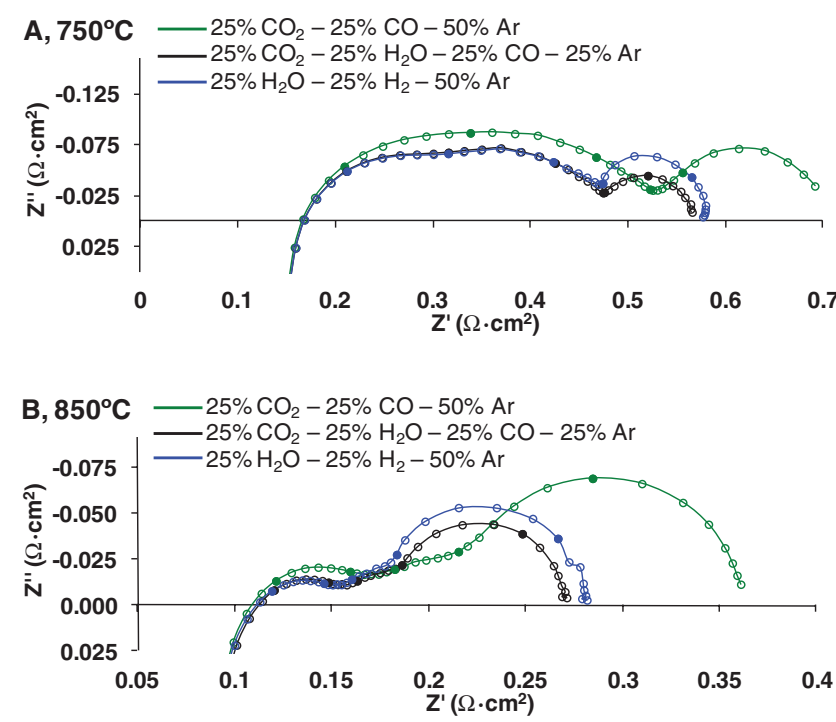

Figure 2. AC characterization at $750^{\circ} \mathrm{C}$ (a) and $850^{\circ} \mathrm{C}$ (b) in mixtures of $25 \%$ $\mathrm{CO}_{2}-25 \% \mathrm{CO}-50 \% \mathrm{Ar}, 25 \% \mathrm{CO}_{2}-25 \% \mathrm{H}_{2} \mathrm{O}-25 \% \mathrm{CO}-25 \% \mathrm{Ar}$, or a mixture of $25 \% \mathrm{H}_{2} \mathrm{O}-25 \% \mathrm{H}_{2}-50 \% \mathrm{Ar}$. 
Table II. Measured cell voltage and ASR for the i-V characterisations shown in Figure 1, Figure 3 and Figure 5. Pure oxygen was passed over the oxygen electrode.

Cell voltage at OCV $(\mathrm{mV})$

\begin{tabular}{|c|c|c|c|c|c|c|c|c|c|}
\hline & \multirow{3}{*}{$\begin{array}{l}\text { Gas composition to the } \\
\text { Ni/YSZ electrode }\end{array}$} & \multicolumn{2}{|c|}{$750^{\circ} \mathrm{C}$} & \multicolumn{2}{|c|}{$850^{\circ} \mathrm{C}$} & \multirow{2}{*}{\multicolumn{2}{|c|}{$\begin{array}{l}\operatorname{ASR}^{\mathrm{a}} \text { in Electrolysis } \\
\text { mode }\left(\Omega \cdot \mathrm{cm}^{2}\right)\end{array}$}} & \multirow{2}{*}{\multicolumn{2}{|c|}{$\begin{array}{c}\text { ASR }^{\mathrm{a}} \text { in Fuel } \\
\text { Cell mode }\left(\Omega \cdot \mathrm{cm}^{2}\right)\end{array}$}} \\
\hline & & \multirow{2}{*}{$\begin{array}{l}\text { Measured } \\
\mathrm{OCV}^{\mathrm{b}}\end{array}$} & \multirow{2}{*}{$\begin{array}{l}\text { Calculated } \\
\mathrm{OCV}^{\mathrm{b}}\end{array}$} & \multirow{2}{*}{$\begin{array}{l}\text { Measured } \\
\mathrm{OCV}^{\mathrm{b}}\end{array}$} & \multirow{2}{*}{$\begin{array}{l}\text { Calculated } \\
\mathrm{OCV}^{\mathrm{b}}\end{array}$} & & & & \\
\hline & & & & & & $750^{\circ} \mathrm{C}$ & $850^{\circ} \mathrm{C}$ & $750^{\circ} \mathrm{C}$ & $850^{\circ} \mathrm{C}$ \\
\hline 1 & $50 \% \mathrm{H}_{2} \mathrm{O}-25 \% \mathrm{H}_{2}-25 \% \mathrm{Ar}$ & 940 & 961 & 912 & 929 & 0.52 & 0.24 & 0.53 & 0.25 \\
\hline 2 & $25 \% \mathrm{H}_{2} \mathrm{O}-25 \% \mathrm{H}_{2}-50 \% \mathrm{Ar}$ & 967 & 991 & 944 & 962 & 0.60 & 0.29 & 0.57 & 0.28 \\
\hline $3^{\mathrm{d}}$ & $\begin{array}{c}25 \% \mathrm{CO}_{2}-25 \% \mathrm{H}_{2} \mathrm{O}-25 \% \\
\mathrm{CO}-25 \% \mathrm{Ar}^{\mathrm{c}}\end{array}$ & 953 & 969 & 913 & 926 & 0.58 & 0.28 & 0.56 & 0.27 \\
\hline 4 & $25 \% \mathrm{CO}_{2}-25 \% \mathrm{CO}-50 \% \mathrm{Ar}$ & 987 & 1003 & 942 & 958 & 0.78 & 0.38 & 0.70 & 0.37 \\
\hline 5 & $50 \% \mathrm{CO}_{2}-25 \% \mathrm{CO}-25 \% \mathrm{Ar}$ & 958 & 973 & 910 & 925 & 0.68 & 0.34 & 0.66 & 0.32 \\
\hline $6^{\mathrm{e}}$ & $50 \% \mathrm{CO}_{2}-25 \% \mathrm{H}_{2}-25 \% \mathrm{Ar}^{\mathrm{c}}$ & 951 & 969 & 910 & 926 & 0.60 & 0.28 & 0.58 & 0.27 \\
\hline
\end{tabular}

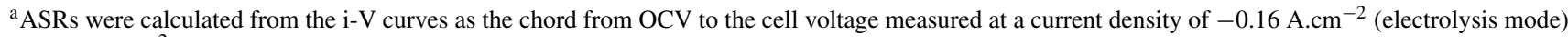
or $0.16 \mathrm{~A} . \mathrm{cm}^{-2}$ (fuel cell mode). The uncertainty for the ASRs calculated from the measured i-V curves is less than one percent.

${ }^{\mathrm{b}}$ The measured OCV is in all cases between 13 and $18 \mathrm{mV}$ below the calculated OCV, and the measured OCV after reduction of the $\mathrm{NiO}$ at start-up was $1051 \mathrm{mV}\left(4 \% \mathrm{H}_{2} \mathrm{O}-96 \% \mathrm{H}_{2}\right)$ whereas the calculated OCV for this gas composition is $1078 \mathrm{mV}$. This points to some leak (gaseous and/or electronic) in the cells.

${ }^{\mathrm{c}}$ The thermodynamic equilibrium composition for the two mixtures at $850^{\circ} \mathrm{C}$ is: $33 \% \mathrm{CO}_{2}-17 \% \mathrm{H}_{2} \mathrm{O}-17 \% \mathrm{CO}-8 \% \mathrm{H}_{2}-25 \%$ Ar, for which the calculated $\mathrm{OCV}$ is also $926 \mathrm{mV}$. At $750^{\circ} \mathrm{C}$, the thermodynamic equilibrium composition for the two mixtures is: $34 \% \mathrm{CO}_{2}-16 \% \mathrm{H}_{2} \mathrm{O}-16 \% \mathrm{CO}_{-}-9 \%$ $\mathrm{H}_{2}-25 \% \mathrm{Ar}$, for which the calculated OCV is also $969 \mathrm{mV}$.

${ }^{\mathrm{d}}$ The gas composition at the outlet of the cell was measured to $34 \% \mathrm{CO}_{2}-17 \% \mathrm{H}_{2} \mathrm{O}-16 \% \mathrm{CO}-8 \% \mathrm{H}_{2}-25 \% \mathrm{Ar}$ at $850{ }^{\circ} \mathrm{C}$ and $35 \% \mathrm{CO}_{2}-15 \%$ $\mathrm{H}_{2} \mathrm{O}-16 \% \mathrm{CO}-9 \% \mathrm{H}_{2}-25 \% \mathrm{Ar}$ at $750^{\circ} \mathrm{C}$.

${ }^{\mathrm{e}}$ The gas composition at the outlet of the cell was measured to $33 \% \mathrm{CO}_{2}-17 \% \mathrm{H}_{2} \mathrm{O}-17 \% \mathrm{CO}-8 \% \mathrm{H}_{2}-25 \% \mathrm{Ar}^{2}$ at $850{ }^{\circ} \mathrm{C}$ and $33 \% \mathrm{CO}_{2}-17 \%$ $\mathrm{H}_{2} \mathrm{O}-16 \% \mathrm{CO}-9 \% \mathrm{H}_{2}-25 \% \mathrm{Ar}$ at $750^{\circ} \mathrm{C}$.
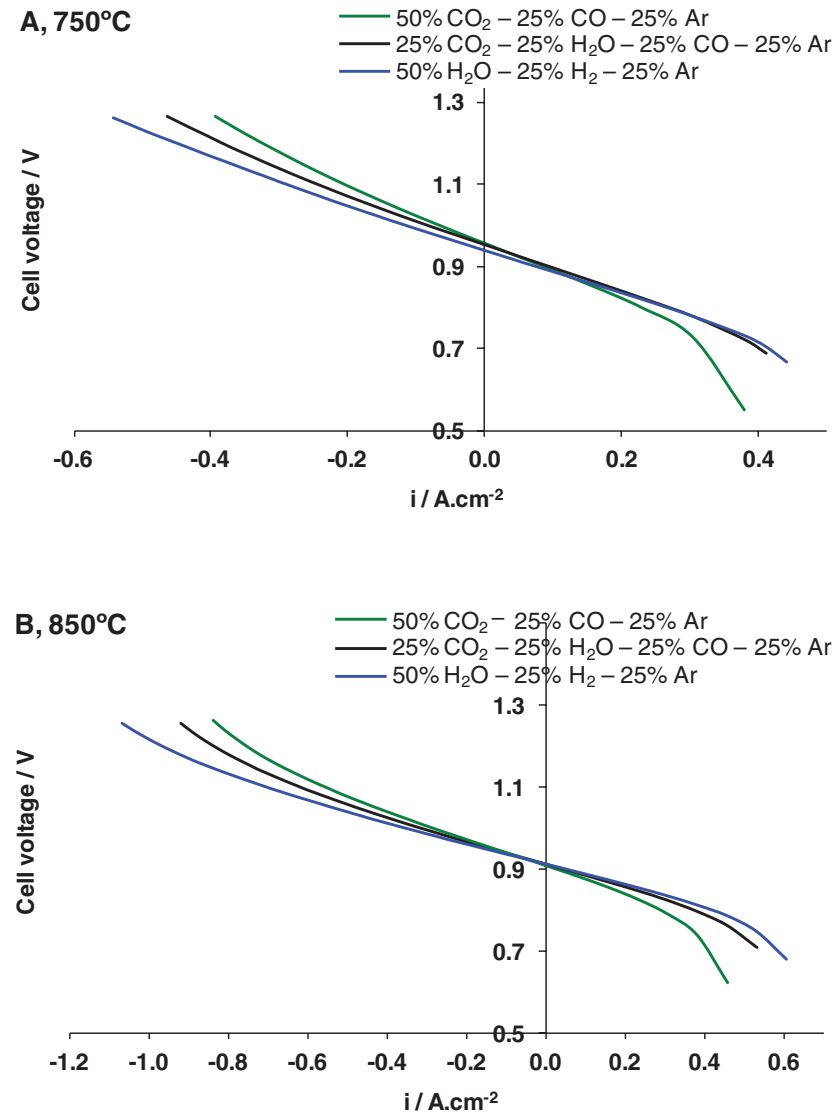

Figure 3. DC characterization at $750^{\circ} \mathrm{C}$ (a) and $850^{\circ} \mathrm{C}$ (b) in mixtures of $50 \%$ $\mathrm{CO}_{2}-25 \% \mathrm{CO}-25 \% \mathrm{Ar}, 25 \% \mathrm{CO}_{2}-25 \% \mathrm{H}_{2} \mathrm{O}-25 \% \mathrm{CO}-25 \% \mathrm{Ar}$ (the same as in Figure 1), or a mixture of $50 \% \mathrm{H}_{2} \mathrm{O}-25 \% \mathrm{H}_{2}-25 \%$ Ar. spectra measured at $\mathrm{OCV}$ for the same $\mathrm{H}_{2} \mathrm{O}-\mathrm{H}_{2}, \mathrm{CO}_{2}-\mathrm{CO}$ or $\mathrm{H}_{2} \mathrm{O}-\mathrm{CO}_{2}-\mathrm{CO}$ mixtures are shown in Figure $2 \mathrm{a}$ and $2 \mathrm{~b}$. The gas compositions and the respective resistances found by break down of the impedance contributions are shown in Table III.
Figure 3 also shows two sets of three i-V curves for mixtures of $\mathrm{H}_{2} \mathrm{O}-\mathrm{H}_{2}, \mathrm{CO}_{2}-\mathrm{CO}$ and $\mathrm{H}_{2} \mathrm{O}-\mathrm{CO}_{2}-\mathrm{CO}$. For $\mathrm{H}_{2} \mathrm{O}-\mathrm{H}_{2}$ and $\mathrm{CO}_{2}-\mathrm{CO}$ mixtures, the cell was operated at less reducing conditions than for the experiments shown in Figure 1 and Figure 2. The gas compositions and measured ASRs for the six $\mathrm{i}-\mathrm{V}$ curves are listed in Table II.

The measured ASR for $\mathrm{CO}_{2}$ electrolysis was higher than for both co-electrolysis and steam electrolysis. For this comparison (Table II and Figure 3) the lowest ASR in electrolysis mode was observed for reduction of $\mathrm{H}_{2} \mathrm{O}$. Also differences were observed in fuel cell mode; the highest ASR was observed for $\mathrm{CO}$ oxidation when only $\mathrm{CO}_{2}$ was present as the oxidizing species. When both $\mathrm{CO}_{2}$ and $\mathrm{H}_{2} \mathrm{O}$ were present a lower ASR was observed for "CO oxidation". The lowest
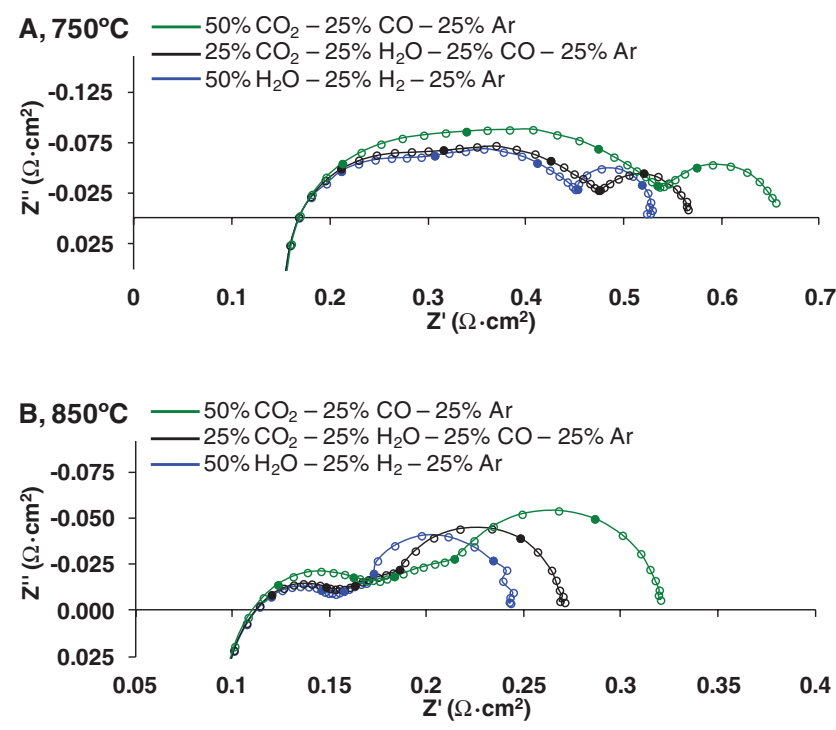

Figure 4. $\mathrm{AC}$ characterization at $750^{\circ} \mathrm{C}$ (a) and $850^{\circ} \mathrm{C}$ (b) in mixtures of $50 \%$ $\mathrm{CO}_{2}-25 \% \mathrm{CO}-25 \% \mathrm{Ar}, 25 \% \mathrm{CO}_{2}-25 \% \mathrm{H}_{2} \mathrm{O}-25 \% \mathrm{CO}-25 \% \mathrm{Ar}$ (the same as in Figure 1), or a mixture of $50 \% \mathrm{H}_{2} \mathrm{O}-25 \% \mathrm{H}_{2}-25 \% \mathrm{Ar}$. 
ASR in fuel cell mode was measured for $\mathrm{H}_{2}$ oxidation in the presence of steam.

Figure 6 shows a comparison between i-V curves measured in mixtures of $\mathrm{CO}_{2}$ with either $\mathrm{CO}$ or $\mathrm{H}_{2}$ as the reducing specie $(50 \%$ $\mathrm{CO}_{2}-25 \% \mathrm{CO}-25 \% \mathrm{Ar}$ or $\left.50 \% \mathrm{CO}_{2}-25 \% \mathrm{H}_{2}-25 \% \mathrm{Ar}\right)$.

Figure 6 and Table II show that the ASR in both electrolysis and fuel cell mode is significantly higher when applying $\mathrm{CO}$ as the reducing specie.

\section{Discussion}

$D C$-characterization. - Continuity of the $\mathrm{i}-\mathrm{V}$ curves across OCV was observed for all reported mixtures, showing that these Ni/YSZ SOCs can work as reversible SOCs in $\mathrm{H}_{2} \mathrm{O}-\mathrm{H}_{2}, \mathrm{CO}_{2}-\mathrm{CO}, \mathrm{CO}_{2}$ $-\mathrm{H}_{2}$ and $\mathrm{H}_{2} \mathrm{O}-\mathrm{CO}_{2}-\mathrm{H}_{2}-\mathrm{CO}$ mixtures. Each i-V curve yields two polarization resistance (ASR) values - one in fuel cell mode (positive currents) and the other in electrolysis mode (negative current). The fuel cell ASR provides information on the oxidation of $\mathrm{H}_{2}$ and/or $\mathrm{CO}$, forming $\mathrm{H}_{2} \mathrm{O}$ and/or $\mathrm{CO}_{2}$ respectively. The electrolysis ASR provides information on the reduction of $\mathrm{H}_{2} \mathrm{O}$ and/or $\mathrm{CO}_{2}$ forming $\mathrm{H}_{2}$ and/or $\mathrm{CO}$ respectively. Typically the observed ASR values are lower in fuel cell mode than in electrolysis mode.

The following section will discuss initially whether any of the reactants are inert in the case of co-electrolysis. Then, the difference in the electrochemical activity of the various compositions will be discussed. Finally, the influence of the WGS / RWGS reactions will be addressed.

Lower ASRs are observed for $\mathrm{H}_{2} \mathrm{O}$ reduction than for $\mathrm{CO}_{2}$ reduction when operated in $25 \% \mathrm{H}_{2} \mathrm{O}-25 \% \mathrm{H}_{2}$ and $25 \% \mathrm{CO}_{2}-25 \% \mathrm{CO}$ (Figure 1, Table II). A slightly lower ASR was observed when operating the SOEC in $25 \% \mathrm{H}_{2} \mathrm{O}-25 \% \mathrm{CO}_{2}-25 \% \mathrm{CO}$. If only steam electrolysis would occur, and $\mathrm{CO}_{2}$ would be inert in the electrochem-
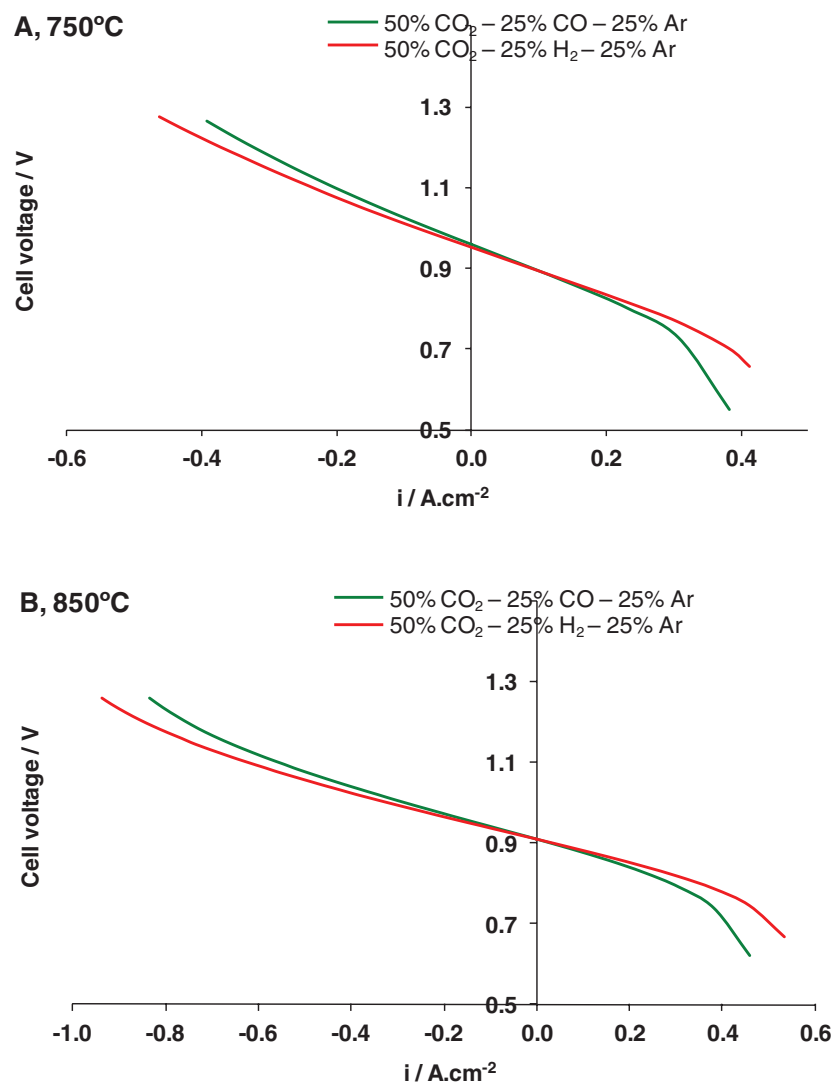

Figure 5. DC characterization at $750^{\circ} \mathrm{C}$ (a) and $850^{\circ} \mathrm{C}$ (b) in mixtures of $50 \%$ $\mathrm{CO}_{2}-25 \% \mathrm{CO}-25 \% \mathrm{Ar}$ (the same as in Figure 3 ) or a mixture of $50 \%$ $\mathrm{CO}_{2}-25 \% \mathrm{H}_{2}-25 \%$ Ar. ical reaction, the observed ASR for co-electrolysis would be identical to the ASR for steam electrolysis. Likewise if only $\mathrm{CO}_{2}$ electrolysis would occur, and $\mathrm{H}_{2} \mathrm{O}$ would be inert in the electrochemical reaction, the observed ASR for co-electrolysis would be similar to the ASR for $\mathrm{CO}_{2}$ electrolysis. That the ASR for co-electrolysis is different from the ASRs of $\mathrm{H}_{2} \mathrm{O}$ and $\mathrm{CO}_{2}$ electrolysis indicates that both $\mathrm{CO}_{2}$ and $\mathrm{H}_{2} \mathrm{O}$ are active in the electrochemical reactions.

The polarization resistance can be subdivided into an electrochemical and a gas conversion part. The gas conversion part is dependendent on the gas composition. To investigate the specific electrochemical reactions, the resistance originating from electrochemical reaction, and not from the gas conversion, must be compared. When keeping the absolute electrode potential (against a well defined reference) constant, and ensuring that the concentrations of the oxidizing / reducing species match, the part of the polarization resistance originating from the gas conversion will be identical. ${ }^{35}$ In this case, the measured ASRs directly reflect the electrochemical activity. The absolute electrode potential in the current experiment is given by the cell voltage (Table II) - which is measured at OCV.

When ensuring identical gas conversion resistance, the ASR for co-electrolysis $\left(25 \% \mathrm{H}_{2} \mathrm{O}-25 \% \mathrm{CO}_{2}-25 \% \mathrm{CO}\right)$ lies between that of $\mathrm{H}_{2} \mathrm{O}$ and $\mathrm{CO}_{2}$ electrolysis $\left(50 \% \mathrm{H}_{2} \mathrm{O}-25 \% \mathrm{H}_{2}\right.$ or $50 \% \mathrm{CO}_{2}-25 \%$ $\mathrm{CO}$ ). This indicates that both $\mathrm{CO}_{2}$ and $\mathrm{H}_{2} \mathrm{O}$ electrolysis occur in these SOCs at the present conditions.

Figure 6 shows that the ASR in both electrolysis and fuel cell mode in $50 \% \mathrm{CO}_{2}-25 \% \mathrm{CO}$ is significantly higher than in $50 \%$ $\mathrm{CO}_{2}-25 \% \mathrm{H}_{2}$. This indicates that $\mathrm{CO}_{2}$ reacts with $\mathrm{H}_{2}$ to produce $\mathrm{H}_{2} \mathrm{O}$ and $\mathrm{CO}$ via the RWGS reaction - increasing the water content at the Ni/YSZ electrode. Thereby the ASR for " $\mathrm{CO}_{2}$ electrolysis" is decreased because the ASR for $\mathrm{H}_{2} \mathrm{O}$ electrolysis is lower than the ASR for $\mathrm{CO}_{2}$ electrolysis. Conversely, Figure 1 and Figure 3 show that the ASR for CO oxidation (operation in fuel cell mode) is significantly lower when $\mathrm{H}_{2} \mathrm{O}$ is added. This indicates that $\mathrm{CO}$ reacts with $\mathrm{H}_{2} \mathrm{O}$ and produces $\mathrm{H}_{2}$ and $\mathrm{CO}_{2}$ via the WGS reaction. In this case, the hydrogen concentration at the $\mathrm{Ni} / \mathrm{YSZ}$ electrode increases, and the ASR for "CO oxidation" decreases because the ASR for $\mathrm{H}_{2}$ oxidation is lower than the ASR for CO oxidation.

The similar ASRs for the co-electrolysis gas mixtures, $25 \% \mathrm{CO}_{2}$ $-25 \% \mathrm{H}_{2} \mathrm{O}-25 \% \mathrm{CO}$ and $50 \% \mathrm{CO}_{2}-25 \% \mathrm{H}_{2}$, implies that the electrode experiences the same gas composition in the two experiments. The equilibrium gas composition is determined by the thermodynamic equilibrium composition - which is identical for the two
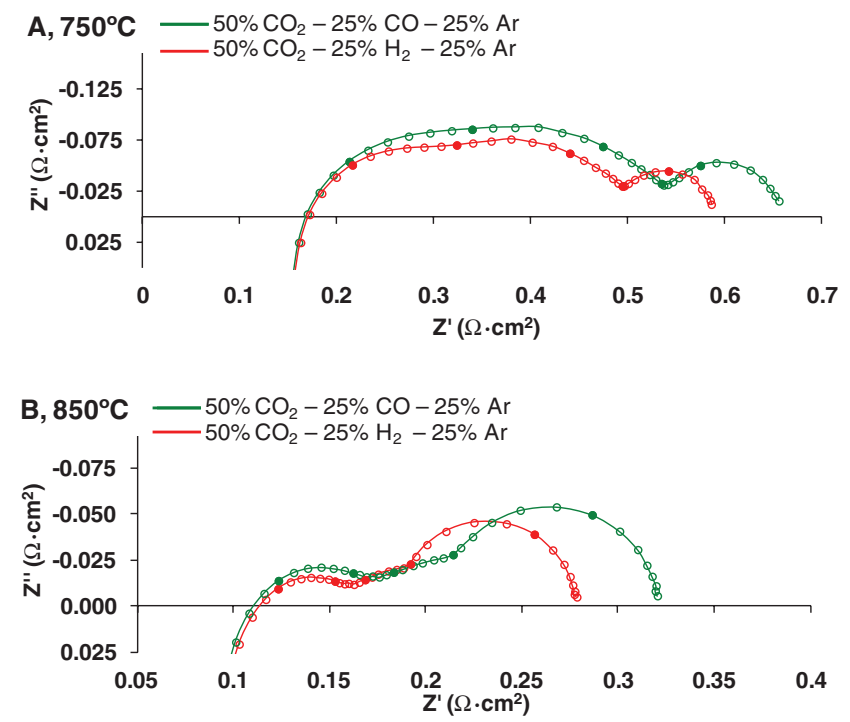

Figure 6. $\mathrm{AC}$ characterization at $750^{\circ} \mathrm{C}$ (a) and $850^{\circ} \mathrm{C}$ (b) in mixtures of $50 \%$ $\mathrm{CO}_{2}-25 \% \mathrm{CO}-25 \% \mathrm{Ar}$ (the same as in Figure 3 ) or a mixture of $50 \% \mathrm{CO}_{2}$ $-25 \% \mathrm{H}_{2}-25 \% \mathrm{Ar}$. 
Table III. Measured ohmic and break down of the polarization resistances for the electrochemical impedance spectra shown in Figure 2, Figure 4 and Figure 6. Pure oxygen was passed over the oxygen electrode. The relative error between experimental and fitted impedance spectra were below $5 \%$ all mixtures.

\begin{tabular}{|c|c|c|c|c|c|c|c|c|c|c|c|c|c|c|c|}
\hline & \multirow{2}{*}{$\begin{array}{l}\text { Gas composition to the } \\
\text { Ni/YSZ electrode }\end{array}$} & \multicolumn{2}{|c|}{$\begin{array}{c}\text { Ohmic } \\
\text { resistance } \\
\left(\Omega \cdot \mathrm{cm}^{2}\right) \\
\end{array}$} & \multicolumn{2}{|c|}{$\begin{array}{c}\text { Resistance for } \\
\text { LSM }_{\mathrm{Hi}} \\
\text { I } \\
\left(\Omega \cdot \mathrm{cm}^{2}\right) \\
\end{array}$} & \multicolumn{2}{|c|}{$\begin{array}{c}\text { Resistance for } \\
\text { TPB } \\
\text { II } \\
\left(\Omega \cdot \mathrm{cm}^{2}\right) \\
\end{array}$} & \multicolumn{2}{|c|}{$\begin{array}{c}\text { Resistance for } \\
\text { LSM }_{\text {Low }} \\
\text { III } \\
\left(\Omega \cdot \mathrm{cm}^{2}\right) \\
\end{array}$} & \multicolumn{2}{|c|}{$\begin{array}{l}\text { Resistance for } \\
\text { Diffusion } \\
\text { IV } \\
\left(\Omega \cdot \mathrm{cm}^{2}\right) \\
\end{array}$} & \multicolumn{2}{|c|}{$\begin{array}{c}\text { Resistance for } \\
\text { Conversion } \\
\mathrm{V} \\
\left(\Omega \cdot \mathrm{cm}^{2}\right) \\
\end{array}$} & \multicolumn{2}{|c|}{$\begin{array}{c}\text { Total } \\
\text { resistances } \\
\left(\Omega \cdot \mathrm{cm}^{2}\right) \\
\end{array}$} \\
\hline & & $750^{\circ} \mathrm{C}$ & $850^{\circ} \mathrm{C}$ & $750^{\circ} \mathrm{C}$ & $850^{\circ} \mathrm{C}$ & $750^{\circ} \mathrm{C}$ & $850^{\circ} \mathrm{C}$ & $750^{\circ} \mathrm{C}$ & $850^{\circ} \mathrm{C}$ & $750^{\circ} \mathrm{C}$ & $850^{\circ} \mathrm{C}$ & $750^{\circ} \mathrm{C}$ & $850^{\circ} \mathrm{C}$ & $750^{\circ} \mathrm{C}$ & $850^{\circ} \mathrm{C}$ \\
\hline 1 & $\begin{array}{l}50 \% \mathrm{H}_{2} \mathrm{O}-25 \% \mathrm{H}_{2}-25 \% \\
\mathrm{Ar}\end{array}$ & 0.128 & 0.072 & 0.117 & 0.037 & 0.067 & 0.032 & 0.121 & 0.013 & 0.023 & 0.017 & 0.072 & 0.074 & 0.528 & 0.245 \\
\hline 2 & $\begin{array}{l}25 \% \mathrm{H}_{2} \mathrm{O}-25 \% \mathrm{H}_{2}-50 \% \\
\mathrm{Ar}\end{array}$ & 0.128 & 0.069 & 0.116 & 0.036 & 0.080 & 0.034 & 0.122 & 0.013 & 0.039 & 0.034 & 0.096 & 0.094 & 0.581 & 0.280 \\
\hline $3^{\mathrm{b}}$ & $\begin{array}{l}25 \% \mathrm{CO}_{2}-25 \% \mathrm{H}_{2} \mathrm{O}-25 \% \\
\mathrm{CO}-25 \% \mathrm{Ar}^{\mathrm{a}}\end{array}$ & 0.127 & 0.070 & 0.117 & 0.038 & 0.083 & 0.034 & 0.121 & 0.013 & 0.031 & 0.036 & 0.088 & 0.080 & 0.567 & 0.271 \\
\hline 4 & $\begin{array}{l}25 \% \mathrm{CO}_{2}-25 \% \mathrm{CO}-50 \% \\
\mathrm{Ar}\end{array}$ & 0.127 & 0.070 & 0.116 & 0.036 & 0.122 & 0.049 & 0.123 & 0.015 & 0.053 & 0.048 & 0.158 & 0.140 & 0.699 & 0.358 \\
\hline 5 & $\begin{array}{l}50 \% \mathrm{CO}_{2}-25 \% \mathrm{CO}-25 \% \\
\mathrm{Ar}\end{array}$ & 0.129 & 0.072 & 0.117 & 0.036 & 0.121 & 0.050 & 0.124 & 0.015 & 0.057 & 0.049 & 0.112 & 0.100 & 0.660 & 0.322 \\
\hline $6^{\mathrm{c}}$ & $\begin{array}{l}50 \% \mathrm{CO}_{2}-25 \% \mathrm{H}_{2}-25 \% \\
\mathrm{Ar}^{\mathrm{a}}\end{array}$ & 0.128 & 0.073 & 0.117 & 0.036 & 0.087 & 0.037 & 0.124 & 0.013 & 0.045 & 0.037 & 0.088 & 0.082 & 0.589 & 0.278 \\
\hline
\end{tabular}

${ }^{\mathrm{a}}$ The thermodynamic equilibrium composition for the two mixtures is: $33 \% \mathrm{CO}_{2}-17 \% \mathrm{H}_{2} \mathrm{O}-17 \% \mathrm{CO}-8 \% \mathrm{H}_{2}-25 \%$ Ar at $850{ }^{\circ} \mathrm{C}$. At $750{ }^{\circ} \mathrm{C}$, the thermodynamic equilibrium composition for the two mixtures is: $34 \% \mathrm{CO}_{2}-16 \% \mathrm{H}_{2} \mathrm{O}-16 \% \mathrm{CO}-9 \% \mathrm{H}_{2}-25 \% \mathrm{Ar}$.

${ }^{b}$ The gas composition at the outlet of the cell was measured to $34 \% \mathrm{CO}_{2}-17 \% \mathrm{H}_{2} \mathrm{O}-16 \% \mathrm{CO}-8 \% \mathrm{H}_{2}-25 \% \mathrm{Ar}^{\circ} 850^{\circ} \mathrm{C}$ and $35 \% \mathrm{CO}_{2}-15 \%$ $\mathrm{H}_{2} \mathrm{O}-16 \% \mathrm{CO}-9 \% \mathrm{H}_{2}-25 \% \mathrm{Ar}$ at $750^{\circ} \mathrm{C}$.

${ }^{\mathrm{c}}$ The gas composition at the outlet of the cell was measured to $33 \% \mathrm{CO}_{2}-17 \% \mathrm{H}_{2} \mathrm{O}-17 \% \mathrm{CO}-8 \% \mathrm{H}_{2}-25 \% \mathrm{Ar}$ at $850{ }^{\circ} \mathrm{C}$ and $33 \% \mathrm{CO}_{2}-17 \%$ $\mathrm{H}_{2} \mathrm{O}-16 \% \mathrm{CO}-9 \% \mathrm{H}_{2}-25 \% \mathrm{Ar}$ at $750^{\circ} \mathrm{C}$.

The resistances are determined by fitting the impedance spectra to an equivalent circuit model consisting of an inductance, a serial resistance, and the five RQ-equivalent circuit. ${ }^{33}$

compositions (Table II and Table III). The measured gas composition at the outlet of the cell (Table II and Table III) was indeed very close to the thermodynamic equilibrium composition (Table II and Table III) showing that equilibrium of the WGS / RWGS reaction is reached within the cell in agreement with previous reports on fast kinetic over nickel catalysts at the present conditions. ${ }^{36}$ These results show that the WGS / RWGS reaction occur in parallel with the electrochemical reactions in these $\mathrm{SOC}$ when operated in mixtures of $\mathrm{H}_{2} \mathrm{O}$, $\mathrm{CO}_{2}, \mathrm{H}_{2}$ and $\mathrm{CO}$.

Based on polarization characteristics (i-V characterization), it was previously stated that $\mathrm{CO}$ is produced solely via the RWGS reaction and that no electrolysis of $\mathrm{CO}_{2}$ occurs during co-electrolysis in nickel based SOCs. ${ }^{25,26}$ This statement was based on similar ASRs measured for steam and co-electrolysis, which were lower than for $\mathrm{CO}_{2}$ electrolysis, when characterizing the $\mathrm{SOC}$ in $54.8 \% \mathrm{H}_{2} \mathrm{O}-22.5 \% \mathrm{H}_{2}$ $-22.7 \% \mathrm{~N}_{2} ; 100 \% \mathrm{CO}_{2}$ and $54.9 \% \mathrm{H}_{2} \mathrm{O}-22.6 \% \mathrm{CO}_{2}-22.5 \% \mathrm{H}_{2}$ at $800^{\circ} \mathrm{C} .{ }^{25,26}$ At first, it should be noted that operating the SOC on pure $\mathrm{CO}_{2}$ may lead to nickel oxidation in the Ni/YSZ electrode as a $\mathrm{CO}_{2}$ concentration above $99.5 \%$ will theoretically lead to oxidation of nickel. The thermodynamic equilibrium composition for the co-electrolysis mixture used in the study is calculated to: $60 \% \mathrm{H}_{2} \mathrm{O}$ $-18 \% \mathrm{CO}_{2}-18 \% \mathrm{H}_{2}-4 \% \mathrm{CO}$ at $800^{\circ} \mathrm{C}$. In these mixtures, the conversion resistance (calculated based on equation 1 , in the supplementary material $^{37}$ ) is approximately 1.2 times higher for steam electrolysis compared to co-electrolysis. Correcting for the different conversion resistance, the electrochemical resistance for co-electrolysis may in this case also lie between that of steam and $\mathrm{CO}_{2}$ electrolysis, showing that both $\mathrm{CO}_{2}$ and $\mathrm{H}_{2} \mathrm{O}$ electrolysis occur in the nickel based SOCs.

The results in the present section clearly show that electrochemical reduction of both $\mathrm{CO}_{2}$ and $\mathrm{H}_{2} \mathrm{O}$ occur during co-electrolysis of $\mathrm{H}_{2} \mathrm{O}$ and $\mathrm{CO}_{2}$ at the present conditions in these Ni/YSZ based SOC produced at DTU Energy conversion (former Ris $\varnothing$ DTU). Furthermore, some $\mathrm{CO}$ may be produced via the reverse water gas shift reaction during co-electrolysis of $\mathrm{H}_{2} \mathrm{O}$ and $\mathrm{CO}_{2}$.

AC-characterization. - The AC characterization is obtained at $\mathrm{OCV}$ and the data therefore contain information on both oxidation and reduction as the oscillation occurs across OCV. The impedance spectra was analyzed by breaking down the polarization losses into five circuits $\left(\mathrm{R}_{\mathrm{LSM}-\mathrm{High}}, \mathrm{R}_{\mathrm{TPB}}, \mathrm{R}_{\mathrm{LSM} \text {-Low }}, \mathrm{R}_{\text {Diffusion, and }} \mathrm{R}_{\text {Conversion }}\right)$. Although the resistances for the individual arcs contributing to the $\mathrm{Ni} / Y S Z$ electrode are larger in $\mathrm{CO}_{2}-\mathrm{CO}$ mixtures, comparison of the impedance spectra for the two mixtures, show that the spectra contain the same arcs. This suggests that the process in principle consists of the same reaction type at the Ni/YSZ electrode irrespective of the gas mixture. Although this model was developed for $\mathrm{H}_{2} \mathrm{O}-\mathrm{H}_{2}$ mixtures, similar goodness of fit was observed in $\mathrm{H}_{2} \mathrm{O}-\mathrm{H}_{2}$ and $\mathrm{CO}_{2}-\mathrm{CO}$ mixtures indicating that the model may be applicable for $\mathrm{CO}_{2}-\mathrm{CO}$ mixtures as well.

The impedance spectra recorded in $25 \% \mathrm{H}_{2} \mathrm{O}-25 \% \mathrm{H}_{2}$ was used as a basis for the fitting. All subsequent impedance spectra were fit firstly by allowing the Ni/YSZ electrode variables to fit, then allowing the LSM/YSZ electrode variables to fit. Consequently mainly $R_{T P B}$, $\mathrm{R}_{\text {Diffusion }}$, and $\mathrm{R}_{\text {Conversion }}$ are affected by the gas changes in agreement with the assignment to processes occurring at the Ni/YSZ electrode. The conversion arc is easy to fit at all temperatures as the arc is distinct in the raw data. The arcs originating from the reaction at the TPB and gas diffusion are the easiest to separate at high temperatures as the diffusion arc does not interfere with the electrochemical response. To investigate the reaction mechanism during co-electrolysis, the focus of the discussion in the AC-characterization will be on the polarization resistance caused by the reaction at the TPB, gas diffusion and gas conversion.

The total resistances measured by the impedance measurements are in good agreement with the ARSs measured by DC characterization (Table II and Table III). The ohmic resistance is comparable with the values obtained when establishing the model, ${ }^{33}$ whereas the resistances obtained for the electrochemical arcs $\left(\mathrm{R}_{\mathrm{LSM}-\mathrm{High}}, \mathrm{R}_{\mathrm{TPB}}\right.$ and $\mathrm{R}_{\mathrm{LSM} \text { - Low }}$ ) are typically $10 \%$ lower. The lower resistances in the present study may be a consequence of oxygen flown to the LSM/YSZ electrode, and the higher steam concentration at the Ni/YSZ electrode, which was previously shown to increase the activity of these SOCs. ${ }^{33,34}$

The electrochemical changes for the Ni/YSZ electrode $\left(R_{T P B}\right.$ $+R_{\text {Diffusion }}+R_{\text {Conversion }}$ ) show the same pattern as discussed above for the $\mathrm{DC}$ characterization, i.e. that both oxidation and reduction of $\mathrm{CO}$ $-\mathrm{CO}_{2}$ and $\mathrm{H}_{2}-\mathrm{H}_{2} \mathrm{O}$ occur in parallel with the WGS / RWGS reaction. 
Table IV. Theoretical polarization resistance caused by gas conversion (calculated from equation 1 in the supplementary material ${ }^{37}$ ) and gas diffusion (calculated from equation 2 and 3 in the supplementary material ${ }^{37}$ ).

\begin{tabular}{|c|c|c|c|c|c|c|c|}
\hline & $\begin{array}{l}\text { Gas composition to the } \\
\mathrm{Ni} / \mathrm{YSZ} \text { electrode }\end{array}$ & \multicolumn{2}{|c|}{$\begin{array}{c}\text { Polarization resistance } \\
\text { caused by } \\
\left(\mathrm{m} \Omega \cdot \mathrm{cm}^{2}\right) \\
\text { Assuming CSTR }\end{array}$} & \multicolumn{2}{|c|}{$\begin{array}{c}\text { Polarization resistance } \\
\text { caused by } \\
\left(\mathrm{m} \Omega \cdot \mathrm{cm}^{2}\right) \\
\text { Assuming PFR }\end{array}$} & \multicolumn{2}{|c|}{$\begin{array}{c}\text { Polarization resistance } \\
\text { caused by } \\
\text { gas diffusion } \\
\left(\mathrm{m} \Omega \cdot \mathrm{cm}^{2}\right)\end{array}$} \\
\hline 1 & $50 \% \mathrm{H}_{2} \mathrm{O}-25 \% \mathrm{H}_{2}-25 \% \mathrm{Ar}$ & 0.077 & 0.085 & 0.039 & 0.042 & 0.019 & 0.022 \\
\hline 2 & $25 \% \mathrm{H}_{2} \mathrm{O}-25 \% \mathrm{H}_{2}-50 \% \mathrm{Ar}$ & 0.103 & 0.113 & 0.052 & 0.057 & 0.031 & 0.035 \\
\hline $3^{\mathrm{a}}$ & $25 \% \mathrm{CO}_{2}-25 \% \mathrm{H}_{2} \mathrm{O}-25 \% \mathrm{CO}-25 \% \mathrm{Ar}^{\mathrm{d}}$ & 0.077 & 0.085 & 0.039 & 0.042 & - & - \\
\hline 6 & $50 \% \mathrm{CO}_{2}-25 \% \mathrm{H}_{2}-25 \% \mathrm{Ar}^{\not}$ & 0.077 & 0.085 & 0.039 & 0.042 & - & - \\
\hline
\end{tabular}

${ }^{a}$ The polarization resistances are calculated based on the outlet (thermodynamic) gas composition.

At first sight, the almost equal $\mathrm{R}_{\mathrm{TPB}}+\mathrm{R}_{\text {Diffusion was observed in } 25 \%}$ $\mathrm{H}_{2} \mathrm{O}-25 \% \mathrm{H}_{2}$ and in $25 \% \mathrm{CO}_{2}-25 \% \mathrm{H}_{2} \mathrm{O}-25 \% \mathrm{CO}$ at $750^{\circ} \mathrm{C}$ could lead to the conclusion that $\mathrm{CO}_{2}$ would be inert in the electrochemical reaction, although the $\mathrm{AC}$ characterization was performed with $25 \%$ $\mathrm{H}_{2}$ for the $\mathrm{H}_{2} \mathrm{O}-\mathrm{H}_{2}$ mixture and a mixture of $16 \% \mathrm{CO}$ and $9 \% \mathrm{H}_{2}$ for the co-electrolysis mixture (equilibrium concentration at $750^{\circ} \mathrm{C}$ ). Based on the different compositions, the $\mathrm{R}_{\mathrm{TPB}}$ and $\mathrm{R}_{\text {Diffusion }}$ are expected to differ. That $\mathrm{R}_{\mathrm{TPB}}$ and $\mathrm{R}_{\text {Diffusion }}$ are almost equal indicates that $\mathrm{CO}_{2}$ is involved in the reaction.

Polarization resistance caused by gas conversion. $-R_{\text {Conversion }}$ can be calculated based on the inlet concentrations according to equation 1 , in the supplementary material. ${ }^{37}$ At $850^{\circ} \mathrm{C}$, the theoretical conversion resistance calculated by equation 1 (stirred tank reactor, CSTR like reactor) is $0.085 \Omega \cdot \mathrm{cm}^{2}$ (and $0.042 \Omega \cdot \mathrm{cm}^{2}$ assuming a plugflow reactor, PFR like reactor $^{38}$ ) in $50 \% \mathrm{H}_{2} \mathrm{O}-25 \% \mathrm{H}_{2}, 25 \%$ $\mathrm{CO}_{2}-25 \% \mathrm{H}_{2} \mathrm{O}-25 \% \mathrm{CO}, 50 \% \mathrm{CO}_{2}-25 \% \mathrm{CO}$, and $50 \%$ $\mathrm{CO}_{2}-25 \% \mathrm{H}_{2}$ and $0.113 \Omega \cdot \mathrm{cm}^{2}$ (and $0.057 \Omega \cdot \mathrm{cm}^{2}$ assuming a PFR) in $25 \% \mathrm{H}_{2} \mathrm{O}-25 \% \mathrm{H}_{2}$ and $25 \% \mathrm{CO}_{2}-25 \% \mathrm{CO}$. In general, in $\mathrm{H}_{2} \mathrm{O}-\mathrm{H}_{2}$ mixtures, the observed conversion arcs (Table II) are between the two theoretical (either assuming a CSTR or PFR). Since the gas passes over the cell "PFR", and has mix through the contact components/cell support "CTSR" it sounds reasonable that the diffusion resistances are between the two theoretical calculated values. However, the observed conversion arcs are too high for $\mathrm{CO}_{2}-\mathrm{CO}$ mixtures at $850^{\circ} \mathrm{C}$. These differences in conversion resistance are most likely caused by the increased diffusion limitations in $\mathrm{CO}_{2} / \mathrm{CO}$ altering the concentration and thereby the conversion resistance. The increased diffusion resistance in $\mathrm{CO}_{2} / \mathrm{CO}$ mixtures is a matter of further analysis within our group. For $\mathrm{H}_{2} \mathrm{O}-\mathrm{H}_{2}$ or $\mathrm{CO}_{2}-$ $\mathrm{CO}$ mixtures a resistance decrease of approximately $25 \%$ is observed when increasing $\mathrm{H}_{2} \mathrm{O}$ or $\mathrm{CO}_{2}$, respectively, from $25 \%$ to $50 \%$ which is in accordance with the calculated conversion resistances.

When decreasing the temperature for $\mathrm{CO}_{2}$ containing mixtures a slight increase in the conversion arc is observed. However, theoretically the conversion arc is expected to decrease. The discrepancy between the measured and the theoretical conversion arcs may originate from small diffusion limitations altering the concentration at the electrochemical active sites, inevitably resulting in an altered conversion resistance. Besides influencing the conversion arc, diffusion limitations are reported to have a distinct arc located at $50-100 \mathrm{~Hz}$, as will be discussed below.

Polarization resistance caused by gas diffusion.-The calculated theoretical diffusion resistances according to equation 2 in the supplementary material ${ }^{37}$ (applying a tortuosity factor of one) are summarized in Table IV (In this study we have applied a tortuosity factor of one in order to be able to compare with the theoretical values, and in order not to introduced values extracted from experimental data). A higher $R_{\text {Diffusion }}$ is observed in $\mathrm{CO}_{2}-\mathrm{CO}$ mixtures compared to $\mathrm{H}_{2} \mathrm{O}-$ $\mathrm{H}_{2}$ mixtures (Table III). The measured $R_{\text {Diffusion }}$ is between 1.4 to 2.8 times higher for $\mathrm{CO}_{2}-\mathrm{CO}$ mixtures compared to $\mathrm{H}_{2} \mathrm{O}-\mathrm{H}_{2}$ mixtures - which is close to the theoretical value for the mixtures with $25 \%$ $\mathrm{H}_{2} \mathrm{O}$ or $\mathrm{CO}_{2}$ (1.4 - 1.7 times higher for $\mathrm{CO}_{2}-\mathrm{CO}$ mixtures). As the theoretical and empirical $R_{\text {Diffusion }}$ values show the same trend it can be concluded that the observed increase in $R_{\text {Diffusion }}$ may be explained by simple gas diffusion - in accordance with equations 2 and 3 in the supplementary material. ${ }^{37}$

When increasing the temperature from 750 to $850^{\circ} \mathrm{C}$ an increase of $13 \%$ in $R_{\text {Diffusion }}$ is anticipated from equations 2 and 4 in the supplementary material ${ }^{37}$ ). However, when increasing the temperature from $750^{\circ} \mathrm{C}$ to $850^{\circ} \mathrm{C}$ a decreased $R_{\text {Diffusion }}$ was observed. Such decreased resistance is expected for surface diffusion. As we have previously discussed, an change in resistance around $100 \mathrm{~Hz}$ may also include surface diffusion, ${ }^{8}$ for which an decreased resistance is expected when increasing the temperature. Although there is a clear increase in resistance when lowering the temperature, there is no consistency in the observed activation energies $\left(\mathrm{E}_{\mathrm{a}}\right.$ lies between $\left.0.1-0.3 \mathrm{eV}\right)$, and experiments performed at a broader (especially lower) temperature range are necessary to conclude on the assignment of the diffusion arc. Further, the average tortuosity factor (in this case, assumed as the difference between the measured and theoretical diffusion resistances) in $\mathrm{H}_{2} \mathrm{O}-\mathrm{H}_{2}$ mixtures is 1.0 , whereas the average tortuosity factor in $\mathrm{CO}_{2}-\mathrm{CO}$ mixtures is 1.2 . Ideally the tortuosity factor should be equal for both mixtures, the higher tortuosity factor in $\mathrm{CO}_{2}-\mathrm{CO}$ mixtures indicates that additional diffusion, such as surface diffusion, may be involved (as will be explained later, the surface diffusion may be more pronounced for $\mathrm{CO}_{2}-\mathrm{CO}$ mixtures as no electron transfer occurs on $\mathrm{CO}_{2}-\mathrm{CO}$ mixtures).

When decreasing the concentration of either $\mathrm{H}_{2} \mathrm{O}$ or $\mathrm{CO}_{2}$ from $50 \%$ to $25 \%, R_{\text {Diffusion }}$ is expected to increase equally by approximately $60 \%$ for the $\mathrm{H}_{2} \mathrm{O}-\mathrm{H}_{2}$ mixture, and by approximately $40 \%$ for the $\mathrm{CO}_{2}$ - $\mathrm{CO}$ mixture. For $\mathrm{H}_{2} \mathrm{O}-\mathrm{H}_{2}$ mixtures the observed increase is between 40 and $50 \%$, whereas, surprisingly a decrease of a few percent $(2-7 \%)$ was observed for $\mathrm{CO}_{2}-\mathrm{CO}$ mixtures. The significant difference when changing the concentrations in $\mathrm{H}_{2} \mathrm{O}-\mathrm{H}_{2}$ mixtures compared to changing the concentrations in $\mathrm{CO}_{2}-\mathrm{CO}$ mixtures may be associated by diffusion of the different surface species in the two mixtures. The surface diffusion resistance of $\mathrm{O}^{2-}$ is expected to be identical in both mixtures. Diffusion of $\mathrm{O}^{2-}$ and $\mathrm{H}^{+}$may be involved in the rate limiting step in $\mathrm{H}_{2} \mathrm{O}-\mathrm{H}_{2}$ mixtures. ${ }^{39}$ In this case, increasing $\mathrm{H}_{2} \mathrm{O}$ concentration will lead to a decreased diffusion resistance on the partly passivated nickel surface. Contrary, for $\mathrm{CO}_{2}-\mathrm{CO}$ mixtures, beside diffusion of $\mathrm{O}^{2-}$, the diffusion of oxygen vacancies may be involved in the rate limiting step. In this case, increasing the $\mathrm{CO}_{2}$ concentration will decrease the oxygen vacancies, and an increased diffusion resistance with increasing $\mathrm{CO}_{2}$ concentration is expected. This is in good agreement with the findings in Figure 2 and Figure 4. This may indicate that the diffusion resistance include, beside gas diffusion, also surface diffusion, and that diffusion of vacancies may be involved in the reaction mechanism in 
$\mathrm{CO}_{2}-\mathrm{CO}$ mixtures. Although the diffusion of oxygen vacancies may play a role in $\mathrm{CO}_{2}-\mathrm{CO}$ mixtures, this does not exclude that also diffusion of $\mathrm{O}^{2-}$ is involved in the reaction. Actually, since only a very small increase in the diffusion resistance is observed when increasing the $\mathrm{CO}_{2}$ concentration, the main reaction mechanism may involve diffusion of $\mathrm{O}^{2-}$. Because the diffusion partly covers surface diffusion, a Gerisher- or Warburg-type of model might have been used to describe the diffusion. As the diffusion covers both surface and gas diffusion, and that the observed resistances are all located within a few decades, and are relatively small for the SOC used in this study, no distinction could be made between the various types of circuit components.

Polarization resistance caused by reaction at the triple phase boundary.-The resistance at the triple phase boundary $\left(\mathrm{R}_{\mathrm{TPB}}\right)$ show notable differences when comparing the reactions in $\mathrm{CO}_{2}-\mathrm{CO}$ and $\mathrm{H}_{2} \mathrm{O}-\mathrm{H}_{2}$ mixtures. The resistances $\left(\mathrm{R}_{T P B}\right)$ are between $1.5-1.8$ times higher for $\mathrm{CO}$ oxidation compared to $\mathrm{H}_{2}$ oxidation. The Gibbs free energy for splitting carbon dioxide is almost identical to the enthalpy for water splitting at $750^{\circ} \mathrm{C}-850^{\circ} \mathrm{C}$. Consequently, the increased $\mathrm{R}_{\mathrm{TPB}}$ in $\mathrm{CO}_{2}-\mathrm{CO}$ mixtures cannot be directly related to the splitting of $\mathrm{H}_{2} \mathrm{O}$ and $\mathrm{CO}_{2}$ and may imply that different reactions at the TPB are involved in the two mixtures. That $\mathrm{R}_{\mathrm{TPB}}$ is larger in $\mathrm{CO}_{2}-\mathrm{CO}$ mixtures compared to in $\mathrm{H}_{2} \mathrm{O}-\mathrm{H}_{2}$ mixtures may be a consequence of impurities at the TPB, which would have an larger effect in $\mathrm{CO}_{2}-$ $\mathrm{CO}$ mixtures, where oxygen transfer on the surface may governor the kinetics, than in $\mathrm{H}_{2} \mathrm{O}-\mathrm{H}_{2}$ mixtures because of proton transfer in $\mathrm{H}_{2} \mathrm{O}$ $-\mathrm{H}_{2}$ mixtures as described in the introduction.

The $\mathrm{R}_{\mathrm{TPB}}$ decreases when increasing the steam concentration at the $\mathrm{Ni} / Y S Z$ electrode, whereas the $\mathrm{CO}_{2}-\mathrm{CO}$ concentration at the $\mathrm{Ni} / Y S Z$ electrode does not affect the $\mathrm{R}_{\mathrm{TPB}}$ notably. Consequently, different rate limiting steps may apply for the Ni/YSZ electrode in the two mixtures. The increase in $\mathrm{R}_{\mathrm{TPB}}$ is most likely associated with $\mathrm{H}_{2} \mathrm{O}_{(g)}+2 e^{-} \rightarrow \mathrm{H}_{(g)}+\mathrm{O}^{2-}$ or $\mathrm{H}_{2} \mathrm{O}_{(\mathrm{g})}+2 e^{-} \rightarrow 2 \mathrm{H}^{+}+\mathrm{O}^{2-}$ in $\mathrm{H}_{2} \mathrm{O}-\mathrm{H}_{2}$ mixtures, whereas $\mathrm{R}_{\mathrm{TPB}}$ is most likely associated with $V_{\ddot{O}}+2 e^{-} \rightarrow V_{O}$ in $\mathrm{CO}_{2}-\mathrm{CO}$ mixtures. That oxygen vacancies may be associated with $\mathrm{R}_{\mathrm{TPB}}$, is supported by the fact that no difference in neither $\mathrm{R}_{\mathrm{TPB}}$ nor $\mathrm{R}_{\text {diffusion }}$ when changing the $\mathrm{CO}_{2}-\mathrm{CO}$ concentration. The higher $\mathrm{R}_{\mathrm{TPB}}$ and associated lower reaction rate in $\mathrm{CO}_{2}-\mathrm{CO}$ mixtures compared to $\mathrm{H}_{2} \mathrm{O}-\mathrm{H}_{2}$ mixtures is thereby a result of: 1) segregation of impurities to the TPB, 2) altered surface and gas diffusion 3 ) altered reaction mechanism in the two mixtures.

Reaction mechanism. - AC and DC characterization performed in $\mathrm{H}_{2} \mathrm{O}-\mathrm{CO}_{2}-\mathrm{H}_{2}-\mathrm{CO}$ mixtures show that both reduction of $\mathrm{H}_{2} \mathrm{O}$ and $\mathrm{CO}_{2}$ as well as oxidation of $\mathrm{H}_{2}$ and $\mathrm{CO}$ occur at the present conditions in these Ni/YSZ based SOCs. Furthermore, $\mathrm{CO}-\mathrm{H}_{2} \mathrm{O}$, and $\mathrm{CO}_{2}-\mathrm{H}_{2}$ react via the WGS / RWGS reaction, producing CO via the RWGS reaction during co-electrolysis.

$\mathrm{AC}$ characterization provides insight in the reaction mechanism in $\mathrm{H}_{2} \mathrm{O}-\mathrm{H}_{2}$ and $\mathrm{CO}_{2}-\mathrm{CO}$ mixtures, and shows significant differences during reactions in the two mixtures. Literature presents a number of reports with suggestions for the reaction mechanisms for oxidation of

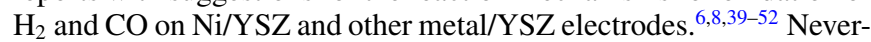
theless, many discrepancies are found in the data, and a comprehensive understanding of the reaction mechanisms is not yet achieved. One possible explanation for the many discrepancies may be that these cermet electrodes are regarded as clean electrode surfaces without impurities, whereas the studied cells (electrodes) will in practice certainly contain impurities. It is well-known that impurities tend to segregate from the bulk of YSZ to grain boundaries, external surfaces and interfaces. ${ }^{53-55}$ Impurity segregation to the interfaces and especially at the active triple phase boundary (TPB) will certainly influence the reaction mechanism.

For Ni/YSZ based SOC operated in electrolysis mode, water may dissociate on both $\mathrm{Ni}$ and YSZ. ${ }^{56}$ Dissociation of water on nickel followed by migration of oxide ions may therefore occur. ${ }^{40,41,49}$ The direct reaction between $\mathrm{H}_{2}$ and $\mathrm{O}^{2-}$ on the YSZ followed by electron migration through zirconia to nickel has also been mentioned as a possibility ${ }^{57}$ although without strong experimental evidence. For some
$\mathrm{Ni} / Y S Z$ electrodes a clear effect of changing from $\mathrm{H}_{2} \mathrm{O}-\mathrm{D}_{2}$ to $\mathrm{D}_{2} \mathrm{O}$ $-\mathrm{D}_{2}{ }^{58,59}$ This indicates that proton migration (diffusion or electrical proton conductions) plays an important role in the ion transfer, and a mechanism involving water adsorbed on YSZ followed by proton migration has been suggested as the main charge transfer mechanism in $\mathrm{H}_{2} \mathrm{O}-\mathrm{H}_{2}$ mixtures. ${ }^{40-44}$ Similar to $\mathrm{H}_{2} \mathrm{O}, \mathrm{CO}_{2}$ may dissociate on either the nickel or YSZ surface, and a mechanism involving the surface migration of oxide ions over nickel and YSZ may occur in $\mathrm{CO}_{2}-\mathrm{CO}$ mixtures also. Further, for $\mathrm{CO}_{2}-\mathrm{CO}$ mixtures, it has been suggested that $\mathrm{CO}_{2}$ adsorbs on oxygen vacancies on the support, and that both $\mathrm{CO}$ and $\mathrm{CO}_{2}$ are directly involved in the electrochemical step. ${ }^{60}$ This reaction involves migration of vacancies at the surface of YSZ. A similar mechanism may occur in $\mathrm{H}_{2} \mathrm{O}-\mathrm{H}_{2}$ mixtures. It has to be noted that the main reaction path, suggested for $\mathrm{H}_{2} \mathrm{O}-\mathrm{H}_{2}$ mixtures, which includes proton migration $\left(\mathrm{H}^{+}\right),{ }^{40-44}$ is not a possible reaction path in $\mathrm{CO}_{2}-\mathrm{CO}$ mixtures.

The differences observed in this paper may be partly explained by the segregation of impurities to the TPB. Segregation of impurities to the TPB will have a larger effect in $\mathrm{CO}_{2}-\mathrm{CO}$ mixtures than in $\mathrm{H}_{2} \mathrm{O}$ $-\mathrm{H}_{2}$ mixtures because proton transfer is only possible in $\mathrm{H}_{2} \mathrm{O}-\mathrm{H}_{2}$ mixtures, resulting in faster kinetics in $\mathrm{H}_{2} \mathrm{O}-\mathrm{H}_{2}$ mixtures. On the other hand, that $\mathrm{R}_{\text {diffusion }}$ increases with decreasing $\mathrm{CO}_{2}$ concentration, whereas it decreases with decreasing $\mathrm{H}_{2} \mathrm{O}$ concentration cannot be explained by segregation of impurities. These observations may be explained by different reaction mechanisms in the two mixtures. In the case of $\mathrm{H}_{2} \mathrm{O}-\mathrm{H}_{2}$ mixtures diffusion of $\mathrm{H}^{+} / \mathrm{O}^{2-} / \mathrm{OH}^{-}$may be involved in the rate limited step. For $\mathrm{CO}_{2}-\mathrm{CO}$ mixtures, along with surface diffusion of $\mathrm{O}^{2-}$, diffusion of oxygen vacancies may play an important role resulting in the observed slower reduction and oxidation rates in $\mathrm{CO}_{2}-\mathrm{CO}$ mixtures compared to $\mathrm{H}_{2} \mathrm{O}-\mathrm{H}_{2}$ mixtures.

That diffusion of $\mathrm{H}^{+} / \mathrm{O}^{2-} / \mathrm{OH}^{-}$, mainly on the nickel surface, may be involved in the rate limited step in $\mathrm{H}_{2} \mathrm{O}-\mathrm{H}_{2}$ mixtures, whereas oxygen vacancies on YSZ may play an role in $\mathrm{CO}_{2}-\mathrm{CO}$ mixtures indicates that impurities adsorbing on the YSZ surface may have a larger effect on the reaction rate in $\mathrm{CO}_{2}-\mathrm{CO}$ mixtures than in $\mathrm{H}_{2} \mathrm{O}$ $-\mathrm{H}_{2}$ mixtures.

\section{Conclusions}

A Ni/YSZ electrode supported Solid Oxide Cell (SOC) was operated as both an fuel cell and an electrolysis cell in mixtures of $\mathrm{H}_{2} \mathrm{O}$ $-\mathrm{H}_{2}, \mathrm{CO}_{2}-\mathrm{CO}, \mathrm{CO}_{2}-\mathrm{H}_{2}$ and $\mathrm{H}_{2} \mathrm{O}-\mathrm{CO}_{2}-\mathrm{CO}$ at $750^{\circ} \mathrm{C}$ and $850^{\circ} \mathrm{C}$. Continuity of the $\mathrm{i}-\mathrm{V}$ curves across OCV was observed for all applied mixtures, showing that these $\mathrm{Ni} / \mathrm{YSZ}$ based $\mathrm{SOCs}$ can work reversible in $\mathrm{H}_{2} \mathrm{O}-\mathrm{H}_{2}, \mathrm{CO}_{2}-\mathrm{CO}, \mathrm{CO}_{2}-\mathrm{H}_{2}$ and $\mathrm{H}_{2} \mathrm{O}-\mathrm{CO}_{2}-\mathrm{CO}$ mixtures. Both $\mathrm{AC}$ and DC characterization show that both reduction of $\mathrm{H}_{2} \mathrm{O}$ and $\mathrm{CO}_{2}$ as well as oxidation of $\mathrm{H}_{2}$ and $\mathrm{CO}$ occur at the present conditions in these Ni/YSZ based SOC. In mixtures of $\mathrm{CO}_{2}-\mathrm{H}_{2} \mathrm{O}-\mathrm{CO}$ and $\mathrm{CO}_{2}-\mathrm{H}_{2}$ equilibrium of the Water Gas Shift (WGS) / Reverse Water Gas Shift (RWGS) reaction is reached, and CO may therefore be produced via the RWGS reaction during co-electrolysis of steam and carbon dioxide. From AC characterization, significant differences during reactions in $\mathrm{H}_{2} \mathrm{O}-\mathrm{H}_{2}$ and $\mathrm{CO}_{2}-\mathrm{CO}$ mixtures were observed implying that the rate limited step in both $\mathrm{H}_{2} \mathrm{O}-\mathrm{H}_{2}$ and $\mathrm{CO}_{2}-\mathrm{CO}$ mixtures in these SOCs is associated with the segregations of impurities to the TPB, and that different reaction mechanisms apply for the mixtures. In the case of $\mathrm{H}_{2} \mathrm{O}-\mathrm{H}_{2}$ mixtures diffusion of $\mathrm{H}^{+} / \mathrm{O}^{2-} / \mathrm{OH}^{-}$ may be involved, whereas for $\mathrm{CO}_{2}-\mathrm{CO}$ mixtures, along with surface diffusion of $\mathrm{O}^{2-}$, diffusion of oxygen vacancies may play an important role resulting in a slower reduction/oxidation rates in $\mathrm{CO}_{2}-\mathrm{CO}$ mixtures compared to in $\mathrm{H}_{2} \mathrm{O}-\mathrm{H}_{2}$ mixtures. Based on the segregation of impurities to the TPB, and that different reaction mechanisms, the $\mathrm{O}^{2-}$ ions has to be forced through the segregation layer in $\mathrm{CO}_{2}-\mathrm{CO}$ mixtures, whereas in $\mathrm{H}_{2} \mathrm{O}-\mathrm{H}_{2}$ mixtures, the current is carried as protons through $\mathrm{Ni}$ and the $\mathrm{YSZ}$, and reactions in $\mathrm{H}_{2} \mathrm{O}-\mathrm{H}_{2}$ mixtures will therefore be less affected by impurities. 


\section{Acknowledgments}

This work was financially supported by The Danish National Advanced Technology Foundations advanced technology platform "Development of 2nd generation bioethanol process and technology", and the Danish Council for Strategic Research, via the Strategic Electrochemistry Research Center (SERC, www.serc.dk).

\section{References}

1. W. Doenitz, R. Schmidberger, E. Steinheil, and R. Streicher, Int. J. Hydrogen Energy, 5, 55 (1980)

2. A. O. Isenberg, Solid State Ionics, 3-4, 431 (1981).

3. Electrochemical hydrogen technologies: Electrochemical production and combustion of hydrogen, H. Wendt (eds.), Elsevier, Amsterdam, The Netherlands (1990).

4. A. Hauch, S. D. Ebbesen, S. H. Jensen, and M. Mogensen, J. Mater. Chem., 18, 2331 (2008).

5. F. Bidrawn, G. Kim, G. Corre, J. T. S. Irvine, J. M. Vohs, and R. J. Gorte, Electrochem. Solid State Lett., 11, B167 (2008).

6. S. D. Ebbesen and M. Mogensen, in Proceedings of the 32nd International Conference \& Exposition on Advanced Ceramics and Composites (ICACC), p. 271 The American Ceramic Society (2008).

7. S. D. Ebbesen, C. Graves, and M. Mogensen, Int. J. Green Energy, 6, 646 (2009).

8. S. D. Ebbesen and M. Mogensen, J. Power Sources, 193, 349 (2009).

9. L. Elikan, J. P. Morris, and C. K. Wu, NASA Research Center, NASA Report CR-2014 (1972).

10. A. O. Isenberg, NASA Research Center, NASA Report CR-185612 (1989).

11. A. O. Isenberg and R. J. Cusick, in 18th Intersociety Conference on Environmental Systems, p. Paper 881040, 1989.

12. A. O. Isenberg and C. E. Verostko, Carbon Dioxide and Water Vapor High Temperature Electrolysis, Johnson Space Center (1989).

13. A. O. Isenberg and C. E. Verostko, in 19th Intersociety Conference on Environmental Systems, p. Paper 891506, 1989.

14. S. H. Jensen, P. H. Larsen, and M. Mogensen, Int. J. Hydrogen Energy, 32, 3253 (2007).

15. K. R. Sridhar, J. Br. Interplanet. Soc., 49, 435 (1996).

16. K. R. Sridhar and B. T. Vaniman, Solid State Ionics, 93, 321 (1997).

17. G. Tao, K. R. Sridhar, and C. L. Chan, Solid State Ionics, 175, 621 (2004).

18. G. Tao, K. R. Sridhar, and C. L. Chan, Solid State Ionics, 175, 615 (2004).

19. R. D. Green, C. C. Liu, and S. B. Adler, Solid State Ionics, 179, 647 (2008).

20. S. D. Ebbesen and M. Mogensen, Electrochem. Solid-State Lett., 13, B106 (2010).

21. S. D. Ebbesen, C. Graves, A. Hauch, S. H. Jensen, and M. Mogensen, J. Electrochem. Soc., 157, B1419 (2010).

22. S. D. Ebbesen, J. Høgh, K. A. Agersted, J. U. Nielsen, and M. Mogensen, Int. J. Hydrogen Energy, 36, 7363 (2011).

23. C. Graves, S. D. Ebbesen, and M. Mogensen, Solid State Ionics, 192, 398 (2010).

24. J. Hartvigsen, S. Elangovan, J. O'Brien, C. Stoots, and J. Herring, ECS Trans., 7, 357 (2007).

25. C. Stoots, J. O'Brien, and J. Hartvigsen, Int. J. Hydrogen Energy, 34, 4208 (2009)

26. C. M. Stoots, J. E. O’Brien, J. S. Herring, and J. J. Hartvigsen, J. Fuelcell. Sci. Tech. 6, 011014 (2009).

27. Z. Zhan, W. Kobsiriphat, J. R. Wilson, M. Pillai, I. Kim, and S. A. Barnett, Energy \& Fuels, 23, 3089 (2009).

28. A. Hagen, R. Barfod, P. V. Hendriksen, Y. L. Liu, and S. Ramousse, J. Electrochem. Soc., 153, A1165 (2006)
29. P. H. Larsen, C. Bagger, S. Linderoth, M. Mogensen, S. Primdahl, M. J. Jørgensen, P. V. Hendriksen, B. Kindl, N. Bonanos, F. W. Poulsen, and K. A. Maegaard, in Proceedings of Solid Oxide Fuel Cell VII (SOFC VII), p. 28, Electrochem. Soc. (2001).

30. M. J. Jørgensen and M. Mogensen, J. Electrochem. Soc., 148, A433 (2001).

31. M. Mogensen and P. V. Hendriksen, in High temperature solid oxide fuel cells Fundamentals, design and applications, p. 261 Elsevier, London (2003).

32. A. Hauch, Solid Oxide Electrolysis Cells - Performance and Durability, PhD Thesis, Risø National Laboratory, Roskilde, Denmark (2007).

33. R. Barfod, M. Mogensen, T. Klemenso, A. Hagen, Y. L. Liu, and P. V. Hendriksen, J. Electrochem. Soc., 154, B371 (2007).

34. A. Hagen, M. Menon, R. Barfod, P. V. Hendriksen, S. Ramousse, and P. H. Larsen, Fuel Cells, 6, 146 (2006).

35. S. Primdahl and M. Mogensen, J. Electrochem. Soc., 145, 2431 (1998).

36. J. M. Wei and E. Iglesia, J. Catal., 224, 370 (2004).

37. See supplementary material at http://dx.doi.org/10.1149/2.076208jes.

38. Journal of The Electrochemical Society, 156(6), B757 (2009).

39. C. J. Wen and D. M. Mason, J. Appl. Electrochem., 8, 81 (1978).

40. P. Holtappels, I. C. Vinke, L. G. J. de Haart, and U. Stimming, J. Electrochem. Soc., 146, 2976 (1999).

41. J. Mizusaki, T. Yamamura, K. Mori, H. Tagawa, K. Hirano, S. Ehara, T. Takagi, M. Hishinuma, H. Sasaki, T. Sogi, Y. Nakamura, and K. Hashimoto, in Proceedings of the 17th Ris $\phi$ International Symposium on Materials Science: High Temperature Electrochemistry: Ceramisc and Metals, Denmark, p. 363, 1996).

42. M. Mogensen, in Proceedings of the 14.Ris $\phi$ international symposium on materials science, p. 77, 1993.

43. M. Mogensen, in Proceedings of the 14.Ris $\phi$ international symposium on materials science, p. 117, 1993.

44. M. Mogensen, J. Høgh, K. V. Hansen, and T. Jacobsen, ECS Trans., 7, 1329 (1993).

45. M. Mogensen and S. Skaarup, Solid State Ionics, 86-88, 1151 (1996).

46. P. Holtappels, L. G. J. de Haart, and U. Stimming, J. Electrochem. Soc., 146, 1620 (1999).

47. J. Mizusaki, H. Tagawa, T. Saito, K. Kamitani, T. Yamamura, K. Hirano, S. Ehara, T. Takagi, T. Hikita, M. Ippommatsu, S. Nakagawa, and K. Hashimoto, J. Electrochem. Soc., 141, 2129 (1994).

48. T. Kawada, N. Sakai, H. Yokokawa, M. Dokiya, M. Mori, and T. Iwata, Solid State Ionics, 40-1, 402 (1990).

49. J. Mizusaki, H. Tagawa, T. Saito, T. Yamamura, K. Kamitani, K. Hirano, S. hara, T. kagi, T. kita, M. pommatsu, S. kagawa, and K. shimoto, Solid State Ionics, 70-71, 52 (1994).

50. M. Ihara, T. Kusano, and C. Yokoyama, J. Electrochem. Soc., 148, A209 (2001)

51. A. Ehn, J. Høgh, M. Graczyk, K. Norrman, L. Montelius, M. Linne, and M. Mogensen, J. Electrochem. Soc., 157, B1588 (2010).

52. V. Yurkiv, D. Starukhin, H. R. Volpp, and W. G. Bessler, J. Electrochem. Soc., 158, B5 (2011)

53. K. V. Hansen, K. Norrman, and M. Mogensen, J. Electrochem. Soc., 151, A1436 (2004).

54. K. V. Jensen, The nickel-YSZ interface. Structure, composition and electrochemical properties at 1000 deg. $C, \mathrm{PhD}$ Thesis, Ris $\emptyset$ National Laboratory, Roskilde, Denmark (2002).

55. K. V. Jensen, R. Wallenberg, I. Khorkendorff, and M. Mogensen, Solid State Ionics, 160, 27 (2003).

56. M. A. Henderson, Surf. Sci. Reports, 46, 1 (2002).

57. N. Q. Minh and T. Takahashi, Science and Technology of Fuel Cells, Elsevier, Amsterdam (1995).

58. S. Primdahl and M. Mogensen, in SOFC VI, The Electrochemical Society Proceeding Series, p. 530, The Electrochemical Society (1999).

59. S. Primdahl and M. Mogensen, Solid State Ionics, 152-153, 597 (2002).

60. T. H. Etsell and S. N. Flengas, J. Electrochem. Soc., 118, 1890 (1971). 